\title{
Odonata of the state of Maranhão, Brazil: Wallacean shortfall and priority areas for faunistic inventories
}

\author{
Rafael Costa Bastos ${ }^{1,2,4}$, Leandro Schlemmer Brasil ${ }^{3 *}{ }^{\circledR}$, Fernando Geraldo Carvalho ${ }^{1,2}$, \\ Lenize Batista Calvãoo ${ }^{3}$, José Orlando de Almeida Silva ${ }^{4}$ \& Leandro Juen ${ }^{5}$ \\ ${ }^{1}$ Universidade Federal do Pará, Programa de Pós-Graduação em Ecologia, Belém, PA, Brasil \\ ${ }^{2}$ Embrapa Amazônia Oriental, Belém, PA, Brasil \\ ${ }^{3}$ Universidade Federal do Pará, Programa de Pós-Graduação em Zoologia, Belém, PA, Brasil \\ ${ }^{4}$ Universidade Federal do Maranhão, Departamento de Licenciatura em Ciências Naturais/Biologia, \\ Codó, MA, Brasil \\ ${ }^{5}$ Universidade Federal do Pará, Laboratório de Ecologia e Conservação, Belém, PA, Brasil \\ *Corresponding author: Leandro Schlemmer Brasil, e-mail: brasil biologia@hotmail.com
}

BASTOS, R.C., BRASIL, L.S., CARVALHO, F.G., CALVÃO, L.B., SILVA, J.O.A., JUEN, L. Odonata of the state of Maranhão, Brazil: Wallacean shortfall and priority areas for faunistic inventories. Biota Neotropica. 19(4): e20190734. http://dx.doi.org/10.1590/1676-0611-BN-2019-0734

\begin{abstract}
Environmental changes are worrying in a scenario with large knowledge gaps on species diversity and distribution. Many species may become extinct before they are known to science. Considering this scenario, the present study aims to evaluate the known distribution of the species recorded for Maranhão state in Brazilian northeast region and discuss knowledge gaps about Odonata indicating the priority areas for faunistic inventories. Using primary and secondary data together, we present convex minimum polygons of the distribution of all the species registered for the state. In addition, we created maps with the richness of species and number of records of Odonata in the Maranhão state. In primary data sample 269 specimens, represented by 17 genera and 30 species were collected. Of the 30 species collected, 17 are new records for the state of Maranhão; of these, $35.29 \%$ are geographically widespread species, occurring in practically all regions of Brazil. Considering the records in the literature, there was a $68 \%$ increase in the number of Odonata species known for Maranhão. The most unexplored region is the Cerrado of the state of Maranhão. Furthermore, the transition regions between Cerrado and Amazônia and between Cerrado and Caatinga are also unknown. All these areas are a priority for faunistic inventories.
\end{abstract}

Keywords: Anisoptera, checklist, patterns of diversity, Zygoptera.

\section{Odonata do estado do Maranhão, Brasil: Déficit wallaceano e áreas prioritárias para inventários faunísticos}

Resumo: As mudanças ambientais são preocupantes em um cenário com muitas lacunas de conhecimento sobre a distribuição das espécies. Várias espécies podem ser extintas antes mesmo de serem conhecidas pela ciência. Considerando este cenário, o presente estudo tem como objetivo avaliar a distribuição conhecida das espécies de Odonata registradas para o Maranhão, na região nordeste do Brasil e discutir sobre as lacunas de conhecimento sobre Odonata, indicando áreas prioritárias para inventários faunísticos. Usando os dados primários e secundários juntos, nós apresentamos polígonos mínimos convexos da distribuição de todas as espécies registradas para o estado neste estudo. Além disso, criamos mapas com a riqueza de espécies e número de registros de Odonata no Maranhão. Para os dados primários foram coletados 269 indivíduos, representando 17 gêneros e 30 espécies. Das 30 espécies amostradas, 17 são novos registros para o Maranhão; dessas, 35,29\% são espécies com ampla distribuição geográfica, ocorrendo em praticamente todas as regiões do Brasil. Considerando os registros na literatura, houve um aumento de $68 \%$ no número de espécies conhecidas para o Maranhão. A região mais desconhecida é o Cerrado do Maranhão. Outrossim, a região de transição Cerrado e Amazônia, e a transição entre Cerrado e Caatinga são também desconhecidas. Todas essas áreas são prioritárias para inventários faunísticos.

Palavras-chave: Anisoptera, checklist, padrões de diversidade, riachos urbanos, Zygoptera. 


\section{Introduction}

Historically, environmental changes have become increasingly frequent and intense, posing a serious problem for the maintenance of biodiversity (Bush et al. 2008). The consequences are more worrying in places where the knowledge about the geographic distribution of the species is restricted or nonexistent (De Marco \& Vianna 2005). This gap is called Wallacean shortfall (Hortal et al. 2015). As a result, many species may be extinct before they are known to science (Pimm et al. 2014). These uncertainties make it difficult to define priority areas for conservation due to the lack of knowledge of the true biodiversity.

In Brazil, the geographical distribution of Odonata is poorly known. Despite of increase of collection effort in many regions the geographical distribution still remains poorly known. In details, some species have already been collected or studied in only approximately $29 \%$ of the country's total area (Miguel et al. 2017). The Northeast region of the country, which contains parts of the Cerrado, Caatinga and Amazon biomes, is one of its most environmentally diverse regions (Leal et al. 2005; MMA 2009). However, the biodiversity of most organisms is not well known within this region, such as aquatic insects of the orders Odonata (De Marco 2008), Ephemeroptera (Shimano et al. 2013) and Heteroptera (Dias-Silva et al. 2013). In this context, Maranhão state stands out negatively among the states of the northeast region as there are few published works on Odonata records (De Marco 2008), which may be a reflection of the shortage of professionals specialized in aquatic entomology in this region of the country (Shimano et al. 2013; Nessimian et al. 2014), as well as the lack of financial resources for the public promotion of science in Brazil (Gibney 2015).

It is known that Odonates are sensitive to environmental alterations in all of their life stages (Mendes et al. 2017). Due to the fact that they are thermoregulators, characteristics related to their ecophysiology, light, which influences the environmental temperature (De Marco et al. 2015) and environmental integrity (Oliveira-Junior et al. 2017) are very important variables for the distribution of species in tropical streams (Monteiro-Júnior et al. 2014; Brasil et al. 2017). Therefore, total or partial removal of riparian vegetation alters light/temperature levels and the environmental integrity of the streams, and consequently destabilizes the communities of Odonata (Carvalho et al. 2013; Oliveira-Junior et al. 2015, 2017). Furthermore, changes in Odonata communities may adversely affect other communities. The absence of these predators should change the trophic organization of riparian zones and this causes loss of ecological integrity (Samways 1993).

Considering that little knowledge exists about Odonata in the Maranhão state (De Marco 2008; Miguel et al. 2017); which is part of the last Brazilian agricultural frontier called MATOPIBA (an acronym of the names of the states of Maranhão, Tocantins, Piaui and Bahia) where there is intense agricultural pressure on natural landscapes for the expansion of soybean cultivation (Spera et al. 2016), studies of this order within this region are extremely relevant. Considering this scenario, the present study's objective evaluates the known distribution of the species recorded for Maranhão state in Brazilian northeast region and discuss knowledge gaps about Odonata indicating the priority areas for faunistic inventories as a conservation allowance.

\section{Material and Methods}

\section{Study area}

The state of Maranhão has an area of $331.937 \mathrm{~km}^{2}$, and includes the phytogeographical domains of Amazonian Forest, Cerrado and Caatinga (Correia-Filho et al. 2011; MMA 2009), according to the Köppen classification system is $A w$ climate type (tropical savanna). This type of climate is primarily characterized by a dry winter (from December to May) and rainy summer (from July to November). In contrast, the state's remaining area, which is predominantly Amazon rainforest, is classified as climate type $\mathrm{Am}$ (tropical rainy), characterized by a long rainy season throughout the year (Peel et al. 2007; Huete et al. 2006).

The study was carried out in tributaries of the Itapecuru River, in the municipality of Codó, located in the eastern meso-region of Maranhão state, Brazil. This municipality is in a Cerrado-Caatinga transition zone, and has an area of 4,698 $\mathrm{km}^{2}$ (Feitosa \& Almeida 2002). The predominant phytogeographical domain is the Cerrado, presenting Cerrado stricto sensu phytophysiognomies, composed mainly of shrub vegetation and medium-sized trees such as Cajueiro (Anacardium occidentale L.); Cerradão, which presents denser vegetation with larger trees such as Bacuri (Platonia insignis Mart.); and riparian forest on the banks of rivers and streams, generally composed of medium and large trees, pioneers, non-pioneers and some shrubs. It also presents the Mata de Cocal formation, where Babaçu (Orbignya phalerata Mart.) (Sousa et al. 2016) and Carnaúba [Copernicia prunifera (Mill.) H.E.Moore] palm trees predominate. The Mata dos Cocais, which extends from the Amazon in central-west Maranhão to the Caatinga in western Piauí, is a type of transitional vegetation cover between tropical, equatorial and semi-arid climates (Nunes et al. 2012). The region's topography varies between flat and gently undulating with modest altitudes relative to the Brazilian relief, with an average of $47 \mathrm{~m}$ (Vasconcelos Gama et al. 2007).

The municipality is drained by the Itapecuru river basin and micro basins of the Codozinho and Saco rivers (Feitosa \& Almeida 2002; Sousa et al. 2016). Riparian vegetation of the Itapecuru River tributaries within the study area is mostly characterized by the Riparian Forest physiognomy. However, streams present considerable levels of alteration resulting from the intensive use of soil for crops and pasture, and the use of water resources for food and leisure (Feitosa \& Almeida 2002). In general, streams' riparian vegetation is narrow or absent and many small streams are ephemeral, containing running water only during periods of high rainfall (such as from January to April) due to the prolonged dry season, typical of northeast Brazil.

\section{Primary data collection}

Odonata adults were collected from nine tributaries belonging to the Itapecuru river basin in the northeast region of Brazil (Fig. 1). The collects were realized twice in each stream, both being in the 2016 year. The streams are perennial, however, eventually becoming temporary in extreme dry events, common in northeastern Brazil. The first collect was realized in May, and the second in Juny. Specimens were collected along the margins of each stream using an entomological net, during a one hour collection period along a $100 \mathrm{~m}$ section. Sampling at each 


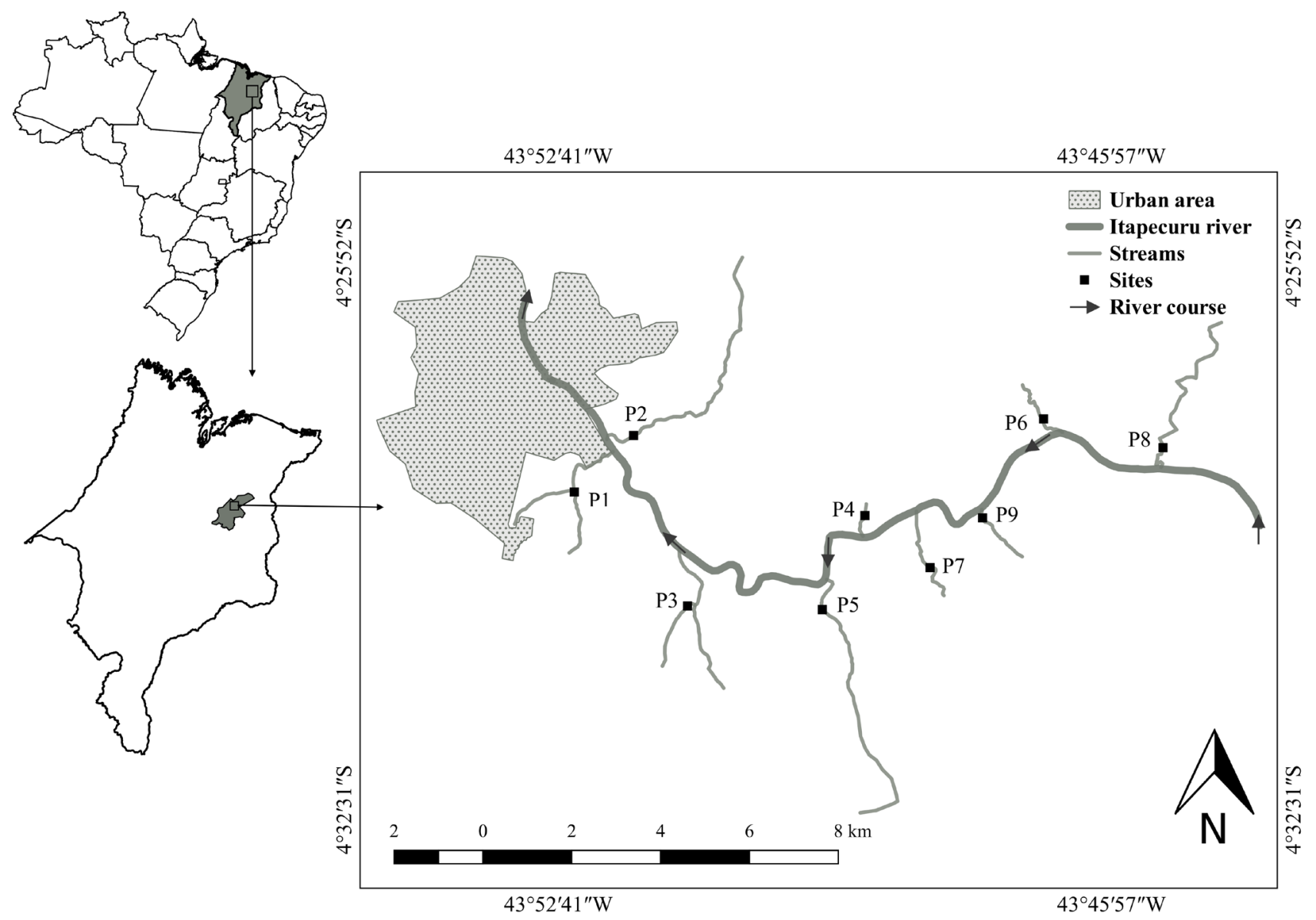

Figure 1. Location of Odonata collection points in tributaries of the Itapecuru River in Codó, Maranhão, Brazil.

point was always performed on sunny days between 11:00 am and 2:00 pm (Monteiro-Júnior et al. 2015). The collected specimens were conditioned and preserved in accordance with the protocol of Lencioni (2006). For the taxonomic identification of the collected specimens, specific keys were used (Heckman 2006; Lencioni 2005, 2006, 2013; Garrison et al. 2006; Belle 1988, 1996; Pessacq 2014; Garrison \& Ellenrieder 2015); when necessary, comparisons were made with specimens already identified and deposited in the collection of the Ecology and Conservation Laboratory, Universidade Federal do Pará; and, expert confirmation.

\section{Secondary data collection}

In order to create species distribution polygons, we used georeferenced distribution data for collected species already used in other studies (Brasil et al. 2018; Calvão et al. 2014), in addition to data that has been compiled from articles, books and museums by De Marco \& Vianna (2005) and Juen \& De Marco (2012) and recently updated by Martins (2016).

\section{Data analysis}

The occurrence data for species collected during this sampling event was tabulated along with the other records for the Brazil. We then selected only the species that occurred in this study and, subsequently, the occurrences plotted and geoprocessed in QGis 2.14.0-Essen (QGis 2011) software. The occurrence points of each species were used to create the Minimum Convex Polygon (Nilsen et al. 2008). This type of polygon is limited by the outermost points of the occurrence set, graphically demonstrating the probable areas of occurrence of these species.

To define the priority areas for faunal inventories, we used all Odonata records for the state of Maranhão (primary and secondary data) for the preparation of two maps, one with species richness values and another with the number of records. We followed the same method used by De Marco \& Vianna (2005), the maps were divided into a grid with 1-degree cells. The maps of the species richness and records were made in the R program using the lets.presab.points functions of the letsR package (R Core Team 2014; Vilela \& Villalobos 2015).

\section{Results}

\section{Description of communities}

A total of 269 specimens represented by 17 genera and 30 species were collected. The suborder Anisoptera presented the highest species richness, with 17 species, representing $56.6 \%$ of the total sampled. The suborder Zygoptera presented only 13 species, with $43.4 \%$ of the total collected. However, considering the abundance of individuals, 
Zygoptera were more representative, with 170 specimens, or $63 \%$ of the total collected; while Anisoptera presented only 99 individuals, representing $37 \%$ of the total.

The most frequently occurring taxa were Acanthagrion aepiolum Tennessen, 2004 found in seven streams (77\% of streams), followed by Acanthagrion kennedii Williamson, 1916 and Erythrodiplax basalis Kirby, 1889 in five streams (56\% of the total), Argia reclusa Selys, 1865 in four streams (or 44\%), and Perithemis sp.1 in three streams (or 33\%). The remaining taxa represents less than $25 \%$ of the total species, whose distribution was restricted to a maximum of two streams (Table 1).

\section{Spatial distribution of species}

Of the 30 Odonata species reported in this study, 17 are new records for the state of Maranhão. Of these new records, 35.29\% are geographically widespread species, occurring in practically all regions of Brazil, from the southernmost Cerrado to the northern Amazon. The remaining $64,71 \%$ are species with a more restricted geographic distribution, occurring in a limited fashion or in a specific region of the country (Table 1; Fig. 2), however the occurrence of Micrathyria paruensis Geijskes, 1963 is the first record of this specie to Brazil.

Table 1. List of Odonata species sampled in the study with points of occurrence and known distribution for the Brazilian states, and species already been recorded in other works for the state of Maranhão. Acronym of the Brazilian states: $\mathrm{AC}=\mathrm{Acre}$. AL= Alagoas. AM=Amazonas. AP= Amapá. BA= Bahia. ES = Espirito Santos. $\mathrm{GO}=$ Goiás. MA = Maranhão. $\mathrm{MG}=$ Minas Gerais. $\mathrm{MS}=$ Mato Grosso do Sul. MT $=$ Mato Grosso. $\mathrm{PA}=\mathrm{Pará} . \mathrm{PB}=\mathrm{Paraíba} . \mathrm{PE}=\mathrm{Pernambuco}$. PR $=$ Paraná. $\mathrm{RJ}=$ Rio de Janeiro. $\mathrm{RO}=$ Rondônia. $\mathrm{RR}=$ Roraima. $\mathrm{RS}=$ Rio Grande do Sul. $\mathrm{SC}=\mathrm{Santa} \mathrm{Catarina} . \mathrm{SP}=\mathrm{São}$ Paulo. TO $=\mathrm{Tocantins}$.

\begin{tabular}{|c|c|c|c|c|}
\hline \multicolumn{5}{|c|}{ Species sampled in the study with known distribution for the Brazilian states and other records for the state of Maranhão. } \\
\hline Suborder/Species & $\begin{array}{l}\text { Points of } \\
\text { occurrence }\end{array}$ & Distribution in Brazil & Other records for Maranhão & Reference \\
\hline \multicolumn{5}{|l|}{ Anisoptera } \\
\hline $\begin{array}{l}\text { Diastatops obscura } \\
\text { Fabricius, } 1775\end{array}$ & $\mathrm{P} 1$ & $\begin{array}{l}\text { AC. AM. AP. BA. ES. GO. MA. MG. } \\
\text { MS. MT. PA. PB. PE. PR. RJ. RO. } \\
\text { RR. SP and TO }\end{array}$ & $\begin{array}{l}\text { Brachymesia herbida Gundlach, } \\
1889\end{array}$ & De Marco (2008) \\
\hline Erythrodiplax basalis & $\begin{array}{l}\text { P1. P3. P4. } \\
\text { P6 and P7 }\end{array}$ & $\begin{array}{l}\text { AC. AM. GO. MA. MS. MT. PA. PE. } \\
\text { PR. RJ. RO. RR. RS and SP. }\end{array}$ & $\begin{array}{l}\text { Erythemis carmelita Williamson, } \\
1923\end{array}$ & De Marco (2008) \\
\hline Erythrodiplax fusca & $\mathrm{P} 4$ and $\mathrm{P} 7$ & $\begin{array}{l}\text { AC. AM. BA. ES. PA. PE. RJ. SP. } \\
\text { GO. MA. MG. MS. MT. PR. RO. RR. } \\
\text { RS and SC }\end{array}$ & $\begin{array}{l}\text { Erythemis peruviana Rambur, } \\
1842\end{array}$ & De Marco (2008) \\
\hline * Erythrodiplax umbrata & $\mathrm{P} 2$ and $\mathrm{P} 9$ & $\begin{array}{l}\text { AC. AM. AP. BA. ES. GO. PA. PE. } \\
\text { PR. MG. MS. MT. RJ. RO. RR. RS } \\
\text { and SP }\end{array}$ & $\begin{array}{l}\text { Erythrodiplax paraguayensis } \\
\text { Förster, } 1905\end{array}$ & De Marco (2008) \\
\hline $\begin{array}{l}\text { ** Micrathyria artemis } \mathrm{Ris}, \\
1911\end{array}$ & P7 & $\begin{array}{l}\text { AM. AP. BA. ES. GO. MG. MS. MT. } \\
\text { PA. RJ. RO and SP }\end{array}$ & $\begin{array}{l}\text { Micrathyria marcella Selys, } \\
1857\end{array}$ & De Marco (2008) \\
\hline $\begin{array}{l}\text { ** Micrathyria divergens } \\
\text { Westfall, } 1992\end{array}$ & P8 & MG & $\begin{array}{l}\text { Micrathyria ocellata Martin, } \\
1897\end{array}$ & De Marco (2008) \\
\hline ** Micrathyria paruensis & $\mathrm{P} 4$ & - & Nephepeltia phryne Perty, 1834 & De Marco (2008) \\
\hline $\begin{array}{l}\text { Micrathyria pseudeximia } \\
\text { Westfall, } 1992\end{array}$ & $\mathrm{P} 1$ & $\begin{array}{l}\text { AM. GO. ES. MA. PA. PR. MG. MS. } \\
\text { MT. RJ and RO }\end{array}$ & $\begin{array}{l}\text { Orthemis discolor Burmeister, } \\
1839\end{array}$ & De Marco (2008) \\
\hline Perithemis sp.2 & P7 & - & Uracis imbuta Burmeister, 1839 & Costa (1997) \\
\hline $\begin{array}{l}\text { ** Perithemis thais Kirby, } \\
1889\end{array}$ & $\mathrm{P} 1$ & $\begin{array}{l}\text { AM. AP. ES. PA. MS. MT. RJ. RO } \\
\text { and SP }\end{array}$ & Micrathyria mengeri Ris, 1919 & Costa $(2002)$ \\
\hline
\end{tabular}


Continuation Table 1.

\begin{tabular}{|c|c|c|c|c|}
\hline Suborder/Species & $\begin{array}{l}\text { Points of } \\
\text { occurrence }\end{array}$ & Distribution in Brazil & Other records for Maranhão & Reference \\
\hline $\begin{array}{l}\text { Zenithoptera lanei Santos, } \\
1941\end{array}$ & $\mathrm{P} 3$ and $\mathrm{P} 4$ & $\begin{array}{l}\text { AC. AM. BA. ES. GO. MA. MS. MT. } \\
\text { PA. PE. RJ. RO. SC. SP and TO }\end{array}$ & Uracis siemensi Kirby, 1897 & $\begin{array}{l}\text { Pujol-luz and } \\
\text { Fonseca (1997) }\end{array}$ \\
\hline \multicolumn{5}{|l|}{ Zygoptera } \\
\hline ** Acanthagrion aepiolum & $\begin{array}{l}\text { P1. P2. P4. } \\
\text { P5. P6. P7 } \\
\text { and P8 }\end{array}$ & MS. PA. PR and SP & Ischnura fluviatilis Selys, 1876 & De Marco (2008) \\
\hline ** Acanthagrion kennedii & $\begin{array}{l}\mathrm{P} 1 . \mathrm{P} 2 . \mathrm{P} 3 . \\
\mathrm{P} 4 \text { and } \mathrm{P} 7\end{array}$ & $\mathrm{PA}$ & & \\
\hline $\begin{array}{l}\text { ** Acanthagrion truncatum } \\
\text { Selys, } 1876\end{array}$ & P8 & BA. GO. MG. MS. MT. SP and TO & & \\
\hline $\begin{array}{l}\text { ** Epipleoneura westfalli } \\
\text { Machado, } 2001\end{array}$ & P5 & MT. PA and RO & & \\
\hline $\begin{array}{l}\text { ** Hetaerina curvicauda } \\
\text { Garrison, } 1990\end{array}$ & P5 & GO. ES. MS. MT and RO & & \\
\hline $\begin{array}{l}\text { Hetaerina sanguínea Selys, } \\
1853\end{array}$ & $\mathrm{P} 6$ and P8 & AM. MA. PA. RO and RR & & \\
\hline * Ischnura capreolus & P8 & $\begin{array}{l}\text { AC. AM. BA. ES. GO. MG. MS. MT. } \\
\text { PA. PE. RJ. RR. RS and SP }\end{array}$ & & \\
\hline $\begin{array}{l}\text { ** Neoneura fulvicollis } \\
\text { Selys, } 1886\end{array}$ & P7 & GO. PA and SP & & \\
\hline
\end{tabular}

* First record for Maranhão state. ** First record for Maranhão state and Northern region.

When we analyze each suborder separately, were found to have similar spatial distributions. The two suborders have records of common species with wide spatial distribution. For instance, Erythrodiplax umbrata Linnaeus, 1758 occurs from the southernmost Cerrado to the northern Brazilian Amazon. Ischnura capreolus, 1861 Hagen occurs the southernmost Cerrado to the northern Brazilian Amazon.

Analysing the Odonata records to Maranhão state we can see that every state practically has priority for faunal inventories. Futhermore, the knowledge gaps are even greater when we consider the distribution of records by Biomes. This happens because although there are few records it focuses on the Amazon portion. The portion of Cerrado, mainly the east of Maranhão is a region where knowledge about the Odonata fauna is almost non-existent (Figure 3).

\section{Discussion}

\section{Community description}

The species with the highest frequency of occurrence and abundance in this study are known as common organisms in altered environments. For example, $A$. aepiolum has a strong relationship with the loss of native vegetation (Rodrigues et al. 2016). Similarly, E. basalis has been shown to be a common species in lentic environments (Calvão et al. 2013), being an excellent indicator of impacted areas (Monteiro-Júnior et al. 2013; Monteiro-Júnior et al. 2015; Oliveira-Junior et al. 2015). A. reclusa was also related to altered environments in previous studies (Dutra \& De Marco 2015). However, A. reclusa was related to environments preserved in the studies of Carvalho et al. (2013) and 
Bastos, R.C. et al.
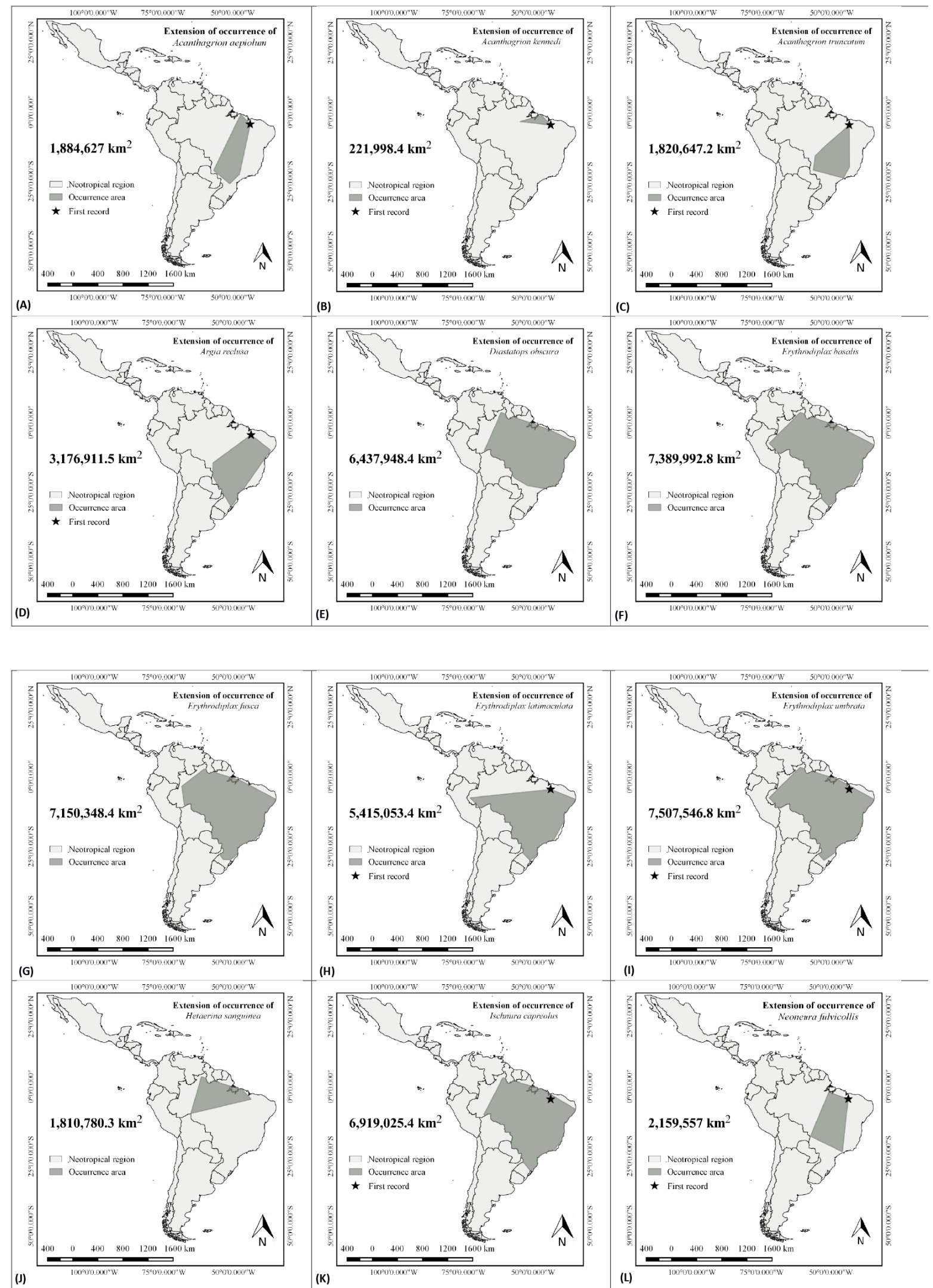

Figure 2. Spatial distribution and new records of Odonata species from Maranhão state, Brazil. 
Odonata of the Maranhão: Areas for inventories
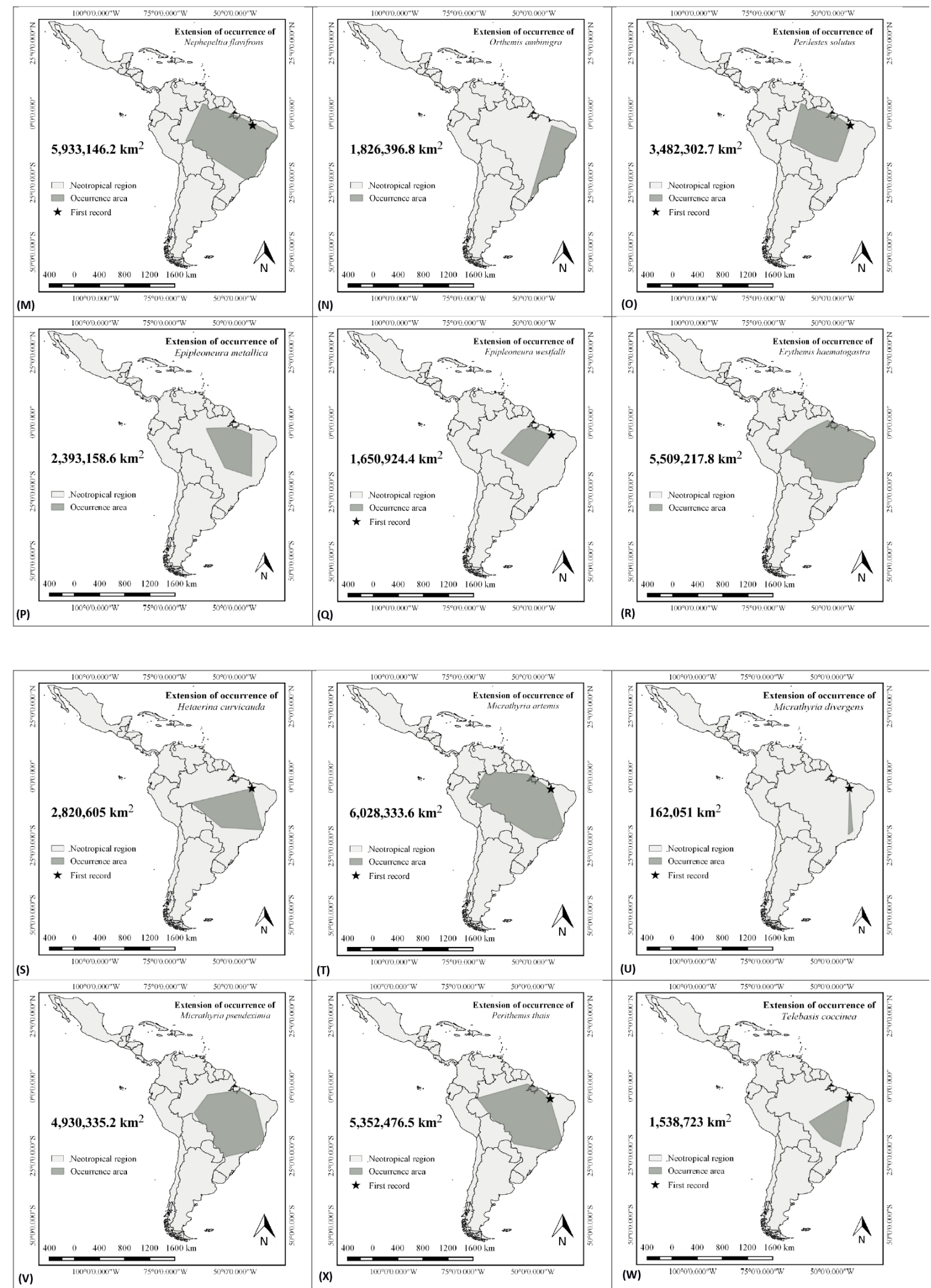

Figure 2. Spatial distribution and new records of Odonata species from Maranhão state, Brazil. 
Bastos, R.C. et al.

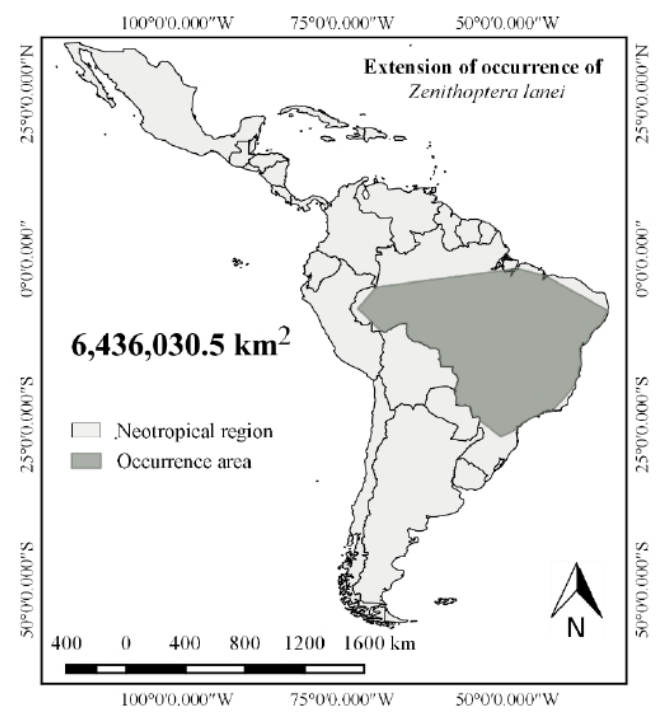

(Y)

Figure 2. Spatial distribution and new records of Odonata species from Maranhão state, Brazil.
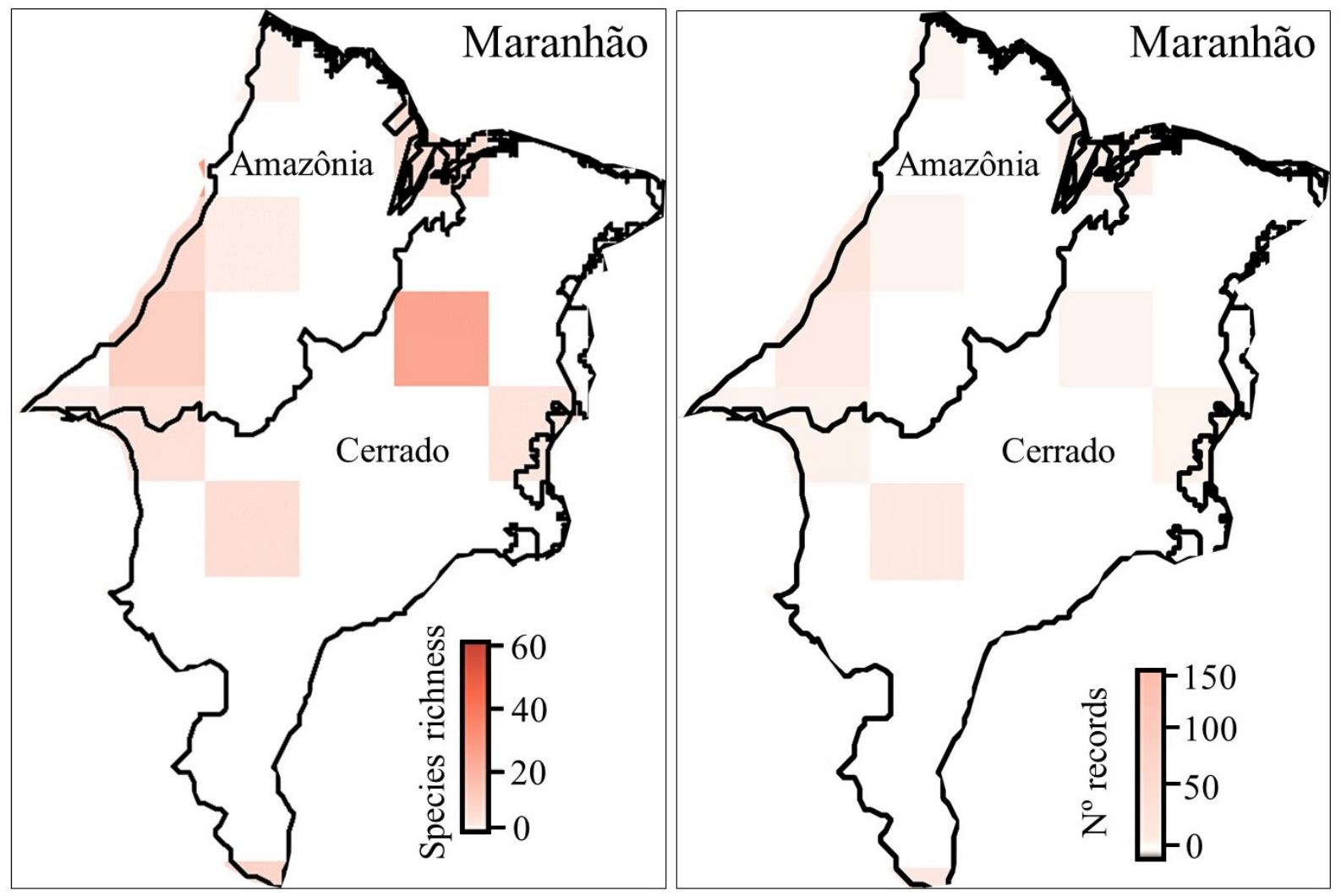

Figure 3. Records and species richness of Odonata in Maranhão state. 
Juen et al. (2014) conducted in the Cerrado and Cerrado-Amazon Forest transition areas. This suggests that other factors, such as resource availability, climate and/or temperature, or even biogeographic patterns (Brasil et al. 2018) may affect the territorial behavior of this specie or the way they perceive environmental variation. It is possible that $A$. reclusa can occur in altered areas, but that have small strip of riparian forest for maintaining a spot of propitious habitat.

It is also worth mentioning that many owners in the region build private pools for family leisure, causing water damming in the channels. In some cases, the stream banks are widened and lined with bags of sand and/or concrete. The water flow in these places is controlled according to the owner's interest. This activity may be favoring the occurrence of generalist organisms, which have a greater tolerance for open areas, such as some species of the genera Erythrodiplax and Micrathyria (De Marco 2008). The change in stream flow may over time lead to a change in species composition, locally wiping out those that are typical of more pristine lotic environments and favoring the entry of more generalist species from more lentic or semi-lentic environments (Juen et al. 2014).

\section{Spatial distribution of species}

Most of the species registered in Maranhão state have a distribution in Cerrado areas. The species M. pseudeximia Westfall, E. latimaculata Ris and E. basalis have occurrence records in practically all the domains, however, they occur in greater concentration in Cerrado. In contrast to these results, $M$. divergens Westfall, which is reported in this study, is recorded only in regions of the Atlantic Forest. Another case similar to this involves the species Orthemis ambinigra Calvert previously reported for Maranhão in the study of De Marco (2008), which also concentrates most of its records in areas of the Atlantic Forest. This results shows the collection gaps in this region (Almeida et al. 2010).

The majority of records for $H$. curvicauda Garrison, T. coccinea Selys, and Epipleoneura westfalli Machado were concentrated in the midwest region of the country, whereas $M$. divergens and A. kennedii were recorded only in the Southeast and Northern regions of the country, respectively. A. aepiolum, which had a large occurrence in the Southern Neotropical region (Lozano 2013), was recently reported for the state of Pará in the study by Calvão et al. (2016), Rondônia state in Brazil and Peru and Bolivia (Lencioni 2017) stateand now for Maranhão in this study.

Only $29 \%$ of the Brazil's total area has geographic distribution data for Odonata and, considering the production of scientific articles, $45 \%$, $20.6 \%$ and $16 \%$ were published in the Southeast, North and Central West regions respectively (Miguel et al. 2017). For this reason, it is possible that the highest number of records in these regions (Southeast, North and Central West), when compared to the Northeast, is a bias related to the greater collection effort in these regions. Therefore, it is important to have a considerable increase in Odonata collections in the Northeast of Brazil so that it is possible to reduce the Wallacean shortfall. This would also allow for a more robust biogeographic analysis of the order (De Marco 2008).

In the present study, $42.31 \%$ of the species are reported for the first time in the Northeast region of Brazil. In addition, the occurrence of $M$. paruensis was recorded, which until then had no certainty in its occurrence for Brazil and was only previously suggested by Heckman (2006). These results suggest that in addition to the Odonata biogeographic factors, a lack of research investments are generating species distribution data that is strongly skewed by the spatial distribution of universities, research centers and specialists (De Marco \& Vianna 2005; Nóbrega \& De Marco 2011).

Greater knowledge of species distribution and environments can be used as a tool for selecting new conservation units (Nóbrega \& De Marco 2011), and also contributes to robust analyses of the socioeconomic and environmental situation on a regional scale. This work contributes to the knowledge of the fauna of Maranhão state, where high species diversity is expected due to its biogeographic and environmental characteristics, however, in contrast it is one of the states where there are fewer studies on Odonata fauna in the country (De Marco \& Vianna 2005). In addition, it enhances the importance of the Northeast region of Brazil for biodiversity conservation, considering that the region is home to several common Odonata species from the Cerrado, Amazon and even the Atlantic Forest. Therefore, despite being an initial effort, with only nine points sampled, this study contributes to minimizing the Wallacean shortfall of the Northeast region and indicates the priority areas. The most unknown region is the Cerrado of the state of Maranhão. Furthermore, the transition regions between Cerrado and Amazônia and between Cerrado and Caatinga are also unknown. All these areas are a priority for faunistic inventories.

\section{Acknowledgements}

LJ thanks for (\#303252/2013-8) received productivity grants and $\mathrm{RCB}$ thanks for receiving master scholarship from Brazilian $\mathrm{CNPq}$ (Conselho Nacional de Desenvolvimento Científico e Tecnológico). LSB is grateful to CAPES (Coordenação de Aperfeiçoamento de Pessoal de Nível Superior) for Postdoctoral scholarships originated from PNPD (Programa Nacional de Pós-Doutorado).

\section{Author Contributions}

Rafael Costa Bastos: Contribution to data collection; Substantial contribution in the concept and design of the study; Contribution to data analysis and interpretation; Contribution to manuscript preparation; Contribution to critical revision, adding intelectual content.

Leandro Schlemmer Brasil: Substantial contribution in the concept and design of the study; Contribution to data analysis and interpretation; Contribution to manuscript preparation; Contribution to critical revision, adding intelectual content.

Fernando Geraldo De Carvalho: Substantial contribution in the concept and design of the study; Contribution to critical revision, adding intelectual content.

Lenize Batista Calvão: Substantial contribution in the concept and design of the study; Contribution to critical revision, adding intelectual content.

José Orlando De Almeida Silva: Substantial contribution in the concept and design of the study; Contribution to critical revision, adding intelectual content.

Leandro Juen: Substantial contribution in the concept and design of the study; Contribution to data analysis and interpretation; Contribution to manuscript preparation; Contribution to critical revision, adding intelectual content. 


\section{Conflicts of interest}

The authors declare that they have no conflict of interest related to the publication of this manuscript.

\section{References}

ALMEIDA, M.C. CORTES, L.G. \& DE MARCO JUNIOR, P. 2010. New records and a niche model for the distribution of two Neotropical damselflies: Schistolobos boliviensis and Tuberculobasis inversa (Odonata: Coenagrionidae). Insect Conservation and Diversity. 3(4): 252-256.

BELLE, J. 1988. A Synopsis of the species of Phyllocycla Calvert, with descriptions of four new taxa and a key to the genera of Neotropical Gomphidae (Odonata, Gomphidae). Tijdschrift voor Entomologie. 131: 73-102.

BELLE, J. 1996. Higher classification of the South-American Gomphidae (Odonata). Zoologische Mededeelingen. 70: 297-324.

BRASIL, L.S. VIEIRA, T.B. DE OLIVEIRA-JUNIOR, J.M.B. DIAS-SILVA, K. \& JUEN, L. 2017. Elements of metacommunity structure in Amazonian Zygoptera among streams under different spatial scales and environmental conditions. Ecology and Evolution. 7(9): 3190-3200.

BRASIL, L.S. OLIVEIRA-JÚNIOR, J.M. CALVÃO, L.B. CARVALHO, F.G. MONTEIRO-JÚNIOR, C.S. DIAS-SILVA, K. \& JUEN, L. 2018. Spatial, biogeographic and environmental predictors of diversity in A mazonian Zygoptera. Insect Conservation and Diversity. 11(2): 174-184.

BUSH, M.B. SILMAN, M. R. MCMICHAEL, C. \& SAATCHI, S. 2008. Fire, climate change and biodiversity in Amazonia: a Late-Holocene perspective. Philosophical Transactions of the Royal Society of London B: Biological Sciences. 363(1498): 1795-1802.

CALVÃO, L.B. VITAL, M.V.C. JUEN, L. LIMA FILHO, G.F.D. OLIVEIRA JÚNIOR, J. M.B.D. PINTO, N.S. \& JÚNIOR, M. 2013. Thermoregulation and microhabitat choice in Erythrodiplax latimaculata males (Anisoptera: Libellulidae). Odonatologica. 4(2): 97-108.

CALVÃO, L.B. JÚNIOR, M. \& BATISTA, J.D. 2014. Odonata (Insecta) from Nova Xavantina, Mato Grosso, Central Brazil: information on species distribution and new records. Check List. 10(2): 299-307.

CALVÃO, L. B. NOGUEIRA, D. S. DE ASSIS MONTAG, L. F. LOPES, M. A \& JUEN, L. 2016. Are Odonata communities impacted by conventional or reduced impact logging?. Forest Ecology and Management. 382: 143-150.

CARVALHO, F.G.D. PINTO, N.S. OLIVEIRA JÚNIOR, J.M.B.D. \& JUEN, L. 2013. Effects of marginal vegetation removal on Odonata communities. Acta Limnologica Brasiliensia. 25(1): 10-18.

CORREIA-FILHO, L. GOMES, E.R. NUNES, O.O. \& LOPES-FILHO, J.B. 2011. Projeto cadastro de fontes de abastecimento por água subterrânea: estado do Maranhão: relatório diagnóstico do município de Codó.

DE MARCO, P. \& VIANNA, D.M. 2005. Distribuição do esforço de coleta de Odonata no Brasil: subsídios para escolha de áreas prioritárias para levantamentos faunísticos. Lundiana, 6(ssupplement).

DE MARCO JÚNIOR, P. 2008. Libellulidae (Insecta: Odonata) from Itapiracó reserve, Maranhão, Brazil: new records and species distribution information. Acta Amazonica. 38(4): 819-822.

DE MARCO, P. BATISTA, J.D. \& CABETTE, H.S.R. 2015. Community assembly of adult odonates in tropical streams: an ecophysiological hypothesis. PLoS One. 10(4): 1-17.

DIAS-SILVA, K. MOREIRA, F.F.F. GIEHL, N.F.D.S. NÓBREGA, C.C. \& CABETTE, H.S.R. 2013. Gerromorpha (Hemiptera: Heteroptera) of eastern Mato Grosso State, Brazil: checklist, new records, and species distribution modeling. Zootaxa. 3736(3): 201-235.

DUTRA, S., \& DE MARCO, P. 2015. Bionomic differences in odonates and their influence on the efficiency of indicator species of environmental quality. Ecological indicators. 49: 132-142.

FEITOSA, A. C. \& ALMEIDA, E. D. 2002. A degradação ambiental do Rio Itapecuru na sede do município de Codó-MA. Cad. Pesq. 13(1): 31-45.
GARRISON, R. W. VON ELLENRIEDER, N. \& LOUTON, J. A. 2006. Dragonfly genera of the New World: an illustrated and annotated key to the Anisoptera. JHU Press.

GARRISON, R. W. \& VON ELLENRIEDER, N. 2015. Damselflies of the genus Argia of the Guiana Shield (Odonata: Coenagrionidae). Zootaxa, 4042: 1-134.

GIBNEY, E. 2015. Brazilian science paralysed by economic slump. Nature. 526(7571): 16-17

HECKMAN, C.W. 2006. Encyclopedia of South American aquatic insects: Odonata-Anisoptera: illustrated keys to known families, genera, and species in South America. Springer Science \& Business Media.

HORTAL, J. DE BELLO, F. DINIZ-FILHO, J.A.F. LEWINSOHN, T.M. LOBO, J.M. \& LADLE, R.J. 2015. Seven shortfalls that beset large-scale knowledge of biodiversity. Annual Review of Ecology, Evolution, and Systematics. 46: 523-549.

HUETE, A.R. DIDAN, K. SHIMABUKURO, Y.E. RATANA, P. SALESKA, S.R. HUTYRA, L. R. WENZE Y. RAMAKRISHNA, R.N. MYNENI, R. 2006. Amazon rainforests green-up with sunlight in dry season. Geophysical research letters. 33(6): 1-4.

JUEN, L. \& DE MARCO, P. 2012. Dragonfly endemism in the Brazilian Amazon: competing hypotheses for biogeographical patterns. Biodiversity and Conservation. 21(13): 3507-3521.

JUEN, L. OLIVEIRA-JUNIOR, J.M.B. SHIMANO, Y. MENDES, T.P. \& CABETTE, H.S.R. 2014. Composição e riqueza de Odonata (Insecta) em riachos diferentes níveis de conservação em um ecótone Cerrado-Floresta Amazônica. Acta Amazonica, 44: 175-184.

LEAL, I.R. SILVA, J.D. TABARELLI, M. \& LACHER JR, T.E. 2005. Mudando o curso da conservação da biodiversidade na Caatinga do Nordeste do Brasil. Megadiversidade. 1(1): 139-146.

LENCIONI, F.A. 2005. Damselflies of Brazil: an illustrated identification guide. v. 1, All Print Editora, São Paulo.

LENCIONI, F. A. 2006. Damselflies of Brazil: an illustrated identification guide. v. 2, All Print Editora, São Paulo.

LENCIONI, F.A. 2013. Diagnoses and discussion of the group 1 and 2 Brazilian species of Heteragrion, with descriptions of four new species (Odonata: Megapodagrionidae). Zootaxa. 3685(1): 1-80.

LENCIONI, F.A.A. 2017. Damselflies of Brazil: An illustrated identification guide: Southeast Region. Ed. do Autor, São Paulo.

LOZANO, F. 2013. Description of three females of the genus Acanthagrion (Odonata: Coenagrionidae) with a key to the females of Argentina. Zootaxa. 3646: 23-38.

MARTINS, F. A. 2016. Determinantes da diversidade de odonata no Brasil: uma abordagem em diferentes escalas espaciais. Universidade Federal de Goiás, Goiás.

MENDES, T.P. OLIVEIRA-JUNIOR, J.M.B. CABETTE, H.S.R. BATISTA, J.D. \& JUEN, L. 2017. Congruence and the biomonitoring of aquatic ecosystems: are odonate larvae or adults the Most effective for the evaluation of impacts. Neotropical entomology. 46(6): 631-641

MIGUEL, T.B. CALVÃO, L.B. VITAL, M.V.C. JUEN, L. 2017. A scientometric study of the order Odonata with special attention to Brazil. International Journal of Odonatology. 20(1): 27-42

MINISTÉRIO DO MEIO AMBIENTE 2009. Plano estrátegico de desenvolvimento industrial do Maranhão, Ministério do Meio Ambiente, Brasília, Goiás, $182 \mathrm{pp}$. Available at http://www.mma.gov.br/estruturas/ secex tal/arquivos/anexo 1 ppcerrado 104.pdf (last access in 08 November 2017)

MONTEIRO-JÚNIOR, C.S. COUCEIRO, S.R.M. HAMADA, N. \& JUEN, L. 2013. Effect of vegetation removal for road building on richness and composition of Odonata communities in Amazonia, Brazil. International Journal of Odonatology. 16(2): 135-144.

MONTEIRO-JÚNIOR, C.D.S.M. JUEN, L. \& HAMADA, N. 2014. Effects of urbanization on stream habitats and associated adult dragonfly and damselfly communities in central Brazilian Amazonia. Landscape and Urban Planning. 127: 28-40. 
MONTEIRO-JÚNIOR, C.D.S.M. JUEN, L. \& HAMADA, N. 2015. Analysis of urban impacts on aquatic habitats in the central Amazon basin: adult odonates as bioindicators of environmental quality. Ecological indicators. 48: 303-311.

NESSIMIAN, J.L. SAMPAIO, B.H.L. \& DUMAS, L.L. 2014. Taxonomia de insetos aquáticos: cenários e tendências para a Amazônia brasileira. Inse.

NILSEN, E.B. PEDERSEN, S. \& LINNELL, J.D. 2008. Can minimum convex polygon home ranges be used to draw biologically meaningful conclusions? Ecological Research. 23(3): 635-639.

NÓBREGA, C.C. \& DE MARCO JR, P. 2011. Unprotecting the rare species: a niche-based gap analysis for odonates in a core Cerrado area. Diversity and Distributions. 17(3): 491-505.

NUNES, L.A.P.L. DA SILVA, D.I.B. DE ARAÚJO, A.S.F. LEITE, L.C.F. \& CORREIA, M.E.F. 2012. Caracterização da fauna edáfica em sistemas de manejo para produção de forragens no Estado do Piauí. Revista Ciência Agronômica. 43(1): 30-37.

OLIVEIRA-JUNIOR, J.M.B. SHIMANO, Y. GARDNER, T.A. HUGHES, R.M. DE MARCO JÚNIOR, P. \& JUEN, L. 2015. Neotropical dragonflies (I nsecta: $\mathrm{O}$ donata) as indicators of ecological condition of small streams in the eastern A mazon. Austral Ecology. 40(6): 733-744.

OLIVEIRA-JUNIOR, J.M.B. JUNIOR, P.D.M. DIAS-SILVA, K. LEITÃO, R.P. LEAL, C. G. POMPEU, P. S. GARDNER, T.A. HUGHES R.M. JUEN, L. 2017. Effects of human disturbance and riparian conditions on Odonata (Insecta) assemblages in eastern Amazon basin streams. LimnologicaEcology and Management of Inland Waters. 66: 31-39.

PEEL, M.C. FINLAYSON, B.L. \& MCMAHON, T.A. 2007. Updated world map of the Köppen-Geiger climate classification. Hydrology and earth system sciences discussions. 4(2): 439-473.

PESSACQ, P. 2014. Synopsis of Epipleoneura (Zygoptera, Coenagrionidae,“P rotoneuridae"), with emphasis on its Brazilian species. Zootaxa. 3872(3): 201-234.
PIMM, S.L. JENKINS, C.N. ABELL, R. BROOKS, T.M. GITTLEMAN, J.L. JOPPA, L.N. ... \& SEXTON, J. O. 2014. The biodiversity of species and their rates of extinction, distribution, and protection. Science. 344(6187): 1-10.

QGIS, D. T. R. R. 2011. Quantum GIS geographic information system (Version 2.14). Open Source Geospatial Foundation Project, 45 Retrieved from https://quantum-gis.softonic.com.br

RODRIGUES, M.E. DE OLIVEIRA ROQUE, F. QUINTERO, J.M.O. DE CASTRO PENA, J.C. DE SOUSA, D.C. \& JUNIOR, P.D.M. 2016. Nonlinear responses in damselfly community along a gradient of habitat loss in a savanna landscape. Biological conservation. 194: 113-120.

SAMWAYS, M. J. 1993. Insects in biodiversity conservation: some perspectives and directives. Biodiversity \& Conservation. 2(3): 258-282.

SHIMANO, Y. SALLES, F.F. \& JUEN, L. 2013. Study of the mayfly order Ephemeroptera (Insecta) in Brazil: a scienciometric review. Revista Brasileira de Entomologia. 57(4): 359-364.

SOUSA, J.R.P. CARVALHO-FILHO, F.S. JUEN, L., \& ESPOSITO, M.C. 2016. Evaluating the Effects of Different Vegetation Types on Necrophagous Fly Communities (Diptera: Calliphoridae; Sarcophagidae): Implications for Conservation. PloS one. 11(10): 1-23.

SPERA, S.A. GALFORD, G.L. COE, M.T. MACEDO, M.N. \& MUSTARD, J.F. 2016. Land-use change affects water recycling in Brazil's last agricultural frontier. Global change biology. 22(10): 3405-3413.

TEAM, R., R. R. 2013. R development core team. RA Lang Environ Stat Comput, 55, 275-286.

VASCONCELLOS GAMA, J. R. LOPES DE SOUZA, A. CALEGARIO, N. \& CAMPOS LANA, G. 2007. Fitossociologia de duas fitocenoses de floresta ombrófila aberta no município de Codó, Estado do Maranhão. Revista Árvore. 31(3): 465-467.

VILELA, B. \& VILLALOBOS, F. 2015. letsR: a new R package for data handling and analysis in macroecology. Methods in Ecology and Evolution. 6(10): 1229-1234. 